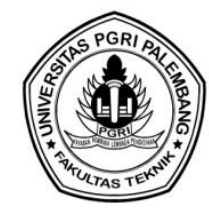

\title{
HUBUNGAN PERSEPSI RISIKO DAN PERILAKU KESELAMATAN BERKENDARA TERHADAP RISIKO KECELAKAAN PADA PENGENDARA SEPEDA MOTOR DI KOTA PALANGKA RAYA
}

\author{
Arie Wiranatha*, Desi Riani, dan Salonten \\ Jurusan/Program Studi Teknik Sipil, Fakultas Teknik, Universitas Palangka Raya \\ "Corresponding Author, Email: ariewiranatha18@gmail.com
}

\begin{abstract}
ABSTRAK
Jumlah kepemilikan kendaraan bermotor di Kota Palangka Raya meningkat berdasarkan data jumlah kendaraan bermotor Kota Palangka Raya yaitu tercatat berjumlah 274.393 unit pada tahun 2019, meningkat dari data tahun 2018 yang berjumlah 259.731 unit. Meningkatnya jumlah kendaraan bermotor dapat menimbulkan kecelakaan lalu lintas. Berdasarkan data Direktorat Jenderal Perhubungan Darat tercatat kecelakaan lebih didominasi oleh sepeda motor sebanyak 73,47\% yaitu berjumlah 140.685 dari total 191.498 kecelakaan. Penelitian ini bertujuan untuk menganalisis hubungan antara perilaku keselamatan berkendara terhadap risiko kecelakaan pada pengendara sepeda motor. Pada penelitian ini digunakan model analisis Structural Equation Model (SEM) yang dibantu dengan software Analisis Moment Of Structure (AMOS) 24. Kuesioner diberikan kepada 348 responden. Karakteristik responden 52\% berjenis kelamin laki-laki, 48\% berjenis kelamin perempuan, dengan rentang usia 20 tahun kebawah (19,5\%) usia antara 21 - 30 tahun $(73,6 \%)$ dan usia diatas 30 tahun (6,9\%). Hasil penelitian menunjukkan bahwa persepsi risiko memiliki hubungan positif terhadap perilaku keselamatan berkendara secara signifikan, dan perilaku keselamatan berkendara memiliki hubungan positif terhadap risiko kecelakaan.
\end{abstract}

Kata Kunci : Perilaku; Structural Equation Model; Moment Of Structure

\begin{abstract}
The number of motorized vehicle ownership in Palangka Raya City increased based on data on the number of motorized vehicles in Palangka Raya City, which was recorded at 274,393 units in 2019, an increase from 2018 data which amounted to 259,731 units. The increasing number of motorized vehicles can cause traffic accidents. Based on data from the Directorate General of Land Transportation, it was recorded that accidents were dominated by motorbikes as much as $73.47 \%$, amounting to 140,685 of the total 191,498 accidents. This study aims to analyze the relationship between safety driving behavior and the risk of accidents on motorcycle riders. In this study, the Structural Equation Model (SEM) analysis model was used which was assisted by Moment Of Structure Analysis (AMOS) 24 software. Questionnaires were given to 348 respondents. Characteristics of respondents $52 \%$ are male, $48 \%$ are female, with an age range of 20 years and under (19.5\%) between $21-30$ years $(73.6 \%)$ and over 30 years (6.9\%). The results showed that risk perception had a significant positive relationship to driving safety behavior, and driving safety behavior had a positive relationship to accident risk.
\end{abstract}

Keywords : Behavior; Structural Equation Model; Moment Of Structure

\section{PENDAHULUAN}

Transportasi adalah kegiatan pemindahan barang (muatan) dan penumpang dari suatu tempat ke tempat lain (Salim 2000). Berdasarkan data jumlah kendaraan bermotor Kota Palangka Raya menurut jenis dan fungsinya pada kantor Pusat Statistik Kota Palangka Raya tercatat bahwa jumlah kepemilikan sepeda motor di Kota Palangka Raya berjumlah 274.393 unit pada tahun 2019 yang meningkat dari data tahun 2018 (259.731 unit). 
Dengan meningkatnya jumlah sepeda motor di Kota Palangka Raya, hal ini mempunyai pontesi dampak buruk terhadap lalu lintas. Salah satu dampaknya adalah kecelakaan lalu lintas yang terjadi dan disebabkan oleh pengendara sepeda motor. Menurut Agung (dalam Azizah 2016), orang yang memiliki persepsi resiko rendah cenderung berkendaraan penuh resiko, seperti berkendara melebihi kecepatan, memotong kendaraan di depan. Hal tersebut tentunya akan memiliki potensi timbulnya kecelakaan lalu lintas. Pengendara tidak akan mengambil keputusan untuk melakukan suatu tindakan (perilaku) yang dipersepsi sebagai berisiko tinggi, bahkan sangat tinggi sehingga akan berdampak pada terancamnya keselamatan, namun tidak jarang pula persepsi pengendara salah. Pengendara tersebut mempersepsikan risiko yang lebih kecil dari pada risiko yang sebenarnya. Akibatnya pengendara mengambil keputusan yang berisiko tinggi sehingga dapat membahayakan keselamatan. Perilaku berkendara yang buruk menjadi salah satu faktor utama penyebab terjadinya kecelakaan, hal ini dikarenakan kurangnya kesadaran terhadap aspek keselamatan berkendara. Perilaku pengendara sepeda motor yang kurang memahami aspek keselamatan berkendara menjadi bahan pertimbangan terhadap perilaku pengendara sepeda motor di Kota Palangka Raya.

Persepsi adalah penilaian subjektif mengenai sesuatu hal. Persepsi risiko berkendara adalah penilaian subjektif mengenai bahaya-bahaya yang ada dijalan, kemampuan berkendara, kemampuan kendaraannya, kemungkinan terjadinya suatu kecelakaan, dan besarnya perhatian pengendara akan konsekuensinya (Budiastomo \& Santoso dalam Lubis 2019). Menurut Chrussiawanti (dalam Sumantri 2018), perilaku keselamatan berkendara adalah suatu upaya yang dilakukan dalam meminimalisir tingkat kecelakaan dan memaksimalkan keamanan dalam berkendara, dan demi menciptakan suatu kondisi yang tidak membahayakan pengendara lain serta menyadari kemungkinan bahaya yang dapat terjadi. Risiko kecelakaan adalah bahaya atau konsekuensi yang muncul akibat suatu peristiwa yang terjadi secara tidak sengaja dan menimbulkan kerugian baik nyawa maupun materil (Lubis 2019).

SEM (structural equation model) adalah model persamaan struktural yang merupakan generasi kedua dari teknik analisis multivariate yang memungkinkan peneliti untuk menguji hubungan antara variabel yang kompleks baik recursive maupun non-recursive, guna memperoleh gambaran menyeluruh mengenai suatu model. Hal ini memungkinkan peneliti untuk melakukan penelitian pengaruh beberapa variabel terhadap variabel lain secara simultan (Ghozali 2008).

\section{METODE PENELITIAN}

Penelitian ini dilakukan di Kota Palangka Raya Provinsi Kalimantan Tengah, yang dilakukan pada bulan Maret hingga Juni 2021. Populasi dalam penelitian ini adalah jumlah kepemilikan sepeda motor yang tercatat pada tahun 2019 di Kota Palangka Raya. Berdasarkan data kantor Pusat Statistik Kota Palangka Raya berjumlah sebanyak 274.393 unit. Jumlah sampel ditentukan berdasarkan tabel penentuan jumlah sampel Isaac \& Michael (terlampir) dengan tingkat akurasi 95\% (batas toleransi kesalahan adalah 5\%) dari 274.393 orang. Maka jumlah sampel yang dibutuhkan sebanyak 348 sampel. Variabel penelitian yang diamati adalah : (1) Variabel Independen adalah variable bebas, pada 
penelitian ini adalah persepsi risiko (PR) pengendara sepeda motor; (2) Variabel Dependen adalah variabel yang nilainya dipengaruhi oleh variabel lain, dan pada penelitian ini adalah : (a) risiko kecelakaan (RK) lalu lintas, (b) perilaku keselamatan berkendara $(\mathrm{PKB})$ pengendara sepeda motor.

Langkah - langkah pengolahan data dalam penelitian ini yaitu (1) Melakukan analisis deskriptif meliputi karakteristik pengendara, persepsi risiko pengendara, perilaku keselamatan berkendara pengendara, dan risiko kecelakaan pengendara; (2) Uji statistik untuk data PR, PKB, dan RK meliputi uji validitas dan reliabilitas; (3) Pembuatan model Structural Equation Model (SEM).

\section{HASIL DAN PEMBAHASAN}

\section{Analisis Structural Equation Model}

Model ini sesuai dengan kriteria yang telah ditetapkan yaitu, nilai p sebesar 0,347 > 0,05 berarti model sesuai dengan data yang sesungguhnya, dan nilai RMSEA sebesar $0,018<0,08$ yang berarti model SEM cocok secara statistik.

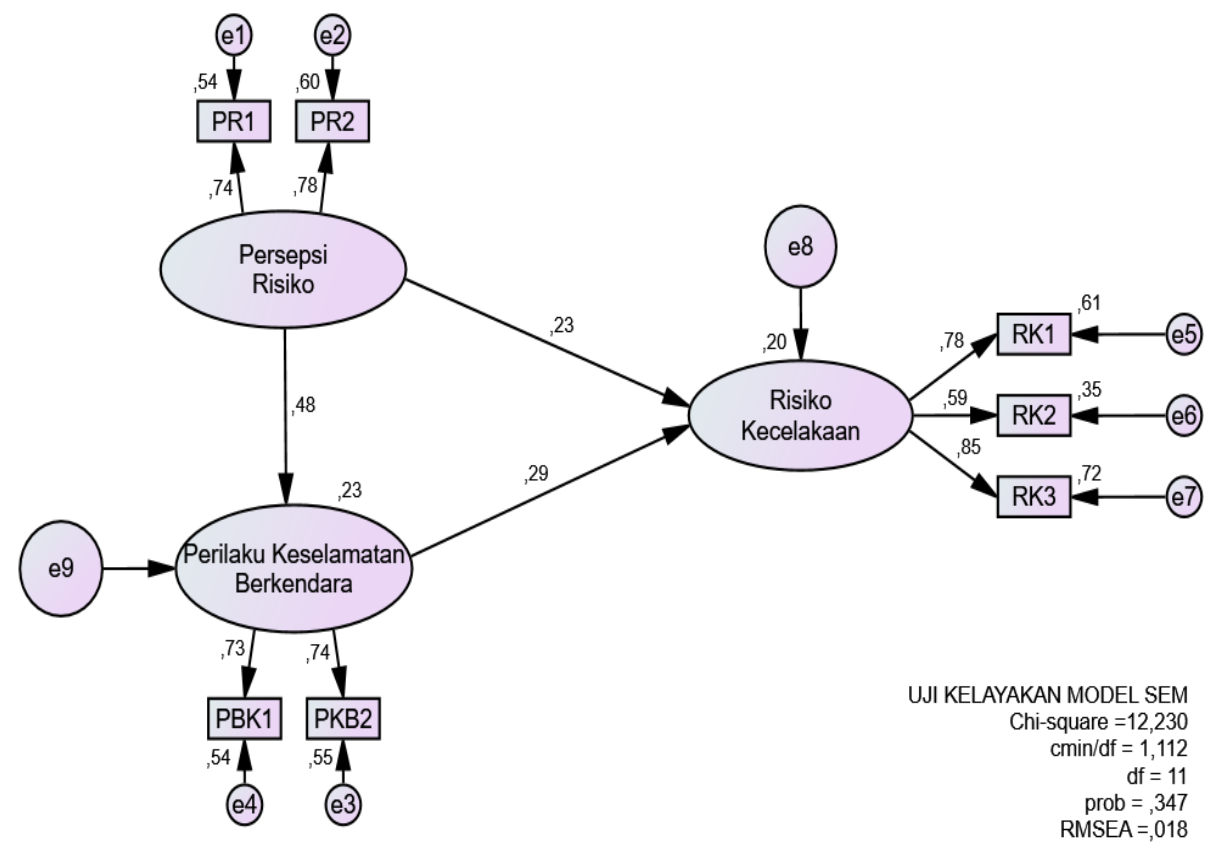

Gambar 1. Structural Equation Model (SEM) Persepsi Risiko, Perilaku Keselamatan Berkendara dan Risiko Kecelakaan

Tabel 1. Hasil Uji Hipotesis

\begin{tabular}{|c|c|c|c|c|c|c|c|}
\hline Hipotesis & & Jalur & & Estimate & C.R. & $\mathrm{P}$ & Hasil \\
\hline $\mathrm{H}_{1}$ & $\begin{array}{c}\text { Persepsi } \\
\text { Risiko }\end{array}$ & $\rightarrow$ & $\begin{array}{c}\text { Perilaku } \\
\text { Keselamatan } \\
\text { Berkendara }\end{array}$ & 0,477 & 5,500 & $* * *$ & Diterima \\
\hline $\mathrm{H}_{2}$ & $\begin{array}{l}\text { Persepsi } \\
\text { Risiko }\end{array}$ & $\rightarrow$ & $\begin{array}{c}\text { Risiko } \\
\text { Kecelakaan }\end{array}$ & 0,229 & 2,764 & 0,006 & Diterima \\
\hline $\mathrm{H}_{3}$ & $\begin{array}{c}\text { Perilaku } \\
\text { Keselamatan } \\
\text { Berkendara }\end{array}$ & $\rightarrow$ & $\begin{array}{c}\text { Risiko } \\
\text { Kecelakaan }\end{array}$ & 0,291 & 3,362 & $* * *$ & Diterima \\
\hline
\end{tabular}




\section{Pembahasan}

a. Persepsi Risiko dan Perilaku Keselamatan Berkendara

Hipotesis pertama memprediksi adanya pengaruh persepsi risiko terhadap perilaku keselamatan berkendara. Berdasarkan hasil perhitungan Structural Equation Model (SEM) dapat dilihat besarnya pengaruh persepsi risiko terhadap perilaku keselamatan berkendara sebesar $(0,477)$ atau 47,7\%, dan menghasilkan nilai C.R. sebesar 5,500. Hal ini menunjukkan bahwa persepsi risiko memiliki hubungan yang positif dengan tingkat signifikansi sebesar 0,006 yaitu kurang dari 0,05 ( $<<5 \%)$, sehingga hipotesis dapat diterima.

b. Persepsi Risiko dan Risiko Kecelakaan

Hipotesis kedua memprediksi adanya pengaruh persepsi risiko terhadap risiko kecelakaan. Berdasarkan hasil perhitungan Structural Equation Model (SEM) dapat dilihat besarnya pengaruh persepsi risiko terhadap risiko kecelakaan sebesar $(0,229)$ atau 22,9\%, dan menghasilkan nilai C.R. sebesar 2,764. Hal ini menunjukan bahwa persepsi risiko memiliki hubungan yang positif dengan tingkat signifikansi sebesar 0,006 yaitu kurang dari 0,05 ( $\mathrm{p}<5 \%$ ), sehingga hipotesis dapat diterima.

c. Perilaku Keselamatan Berkendara dan Risiko Kecelakaan

Hipotesis ketiga memprediksi adanya pengaruh perilaku keselamatan berkendara terhadap risiko kecelakaan. Berdasarkan hasil perhitungan Structural Equation Model (SEM) dapat dilihat besarnya pengaruh perilaku keselamatan berkendara terhadap risiko kecelakaan sebesar $(0,291)$ atau $29,1 \%$ dan menghasilkan nilai C.R. sebesar 3,362. Hal ini menunjukan bahwa perilaku keselamatan berkendara memiliki hubungan yang positif dengan tingkat signifikansi sebesar 0,000 yaitu kurang dari 0,05 ( $\mathrm{p}<5 \%$ ), sehingga hipotesis dapat diterima.

\section{KESIMPULAN}

Berdasarkan hasil penelitian dapat disimpulkan beberapa hal terkait dengan perilaku keselamatan berkendara pada pengendara sepeda motor di Kota Palangka Raya, antara lain sebagai berikut :

1. Karakteristik pengendara sepeda motor di Kota Palangka Raya terdiri dari 52\% lakilaki dan 48\% Perempuan, dengan rentang usia 20 tahun kebawah sebanyak 19,5\%, usia antara 21-30 tahun (73,6\%) dan usia diatas 30 tahun $(6,9 \%)$. Dengan pendidikan terakhir, SMP 13,8\%, SMA 65,8\% dan Perguruan Tinggi 20,4\%. Memiliki SIM C $82,8 \%$, dan $17,2 \%$ tidak memiliki SIM C, dengan $66,1 \%$ mengikuti tes pembuatan SIM dan 33,9\% tidak mengikuti tes pembuatan SIM.

2. Berdasarkan hasil penelitian didapat hubungan antar persepsi risiko dengan perilaku keselamatan berkendara terhadap risiko kecelakaan sebagai berikut:

a. Persepsi risiko berpengaruh positif sebesar $47,7 \%$ terhadap perilaku keselamatan berkendara dan memiliki hubungan yang signifikan.

b. Persepsi risiko berpengaruh positif sebesar 22,9\% terhadap risiko kecelakaan dan memiliki hubungan yang signifikan.

c. Perilaku keselamatan berkendara berpengaruh positif sebesar $29,1 \%$ terhadap risiko kecelakaan dan memiliki hubungan yang signifikan. 


\section{DAFTAR PUSTAKA}

Azizah, M. H. (2016). Faktor yang berhubungan dengan perilaku keselamatan berkendara (safety riding) pada mahasiswa (studi pada mahasiswa FMIPA UNNES angkatan 2008-2015)(Doctoral dissertation, Universitas Negeri Semarang).

Ghozali, I., (2005). Aplikasi Analisis Multivariate dengan SPSS. Semarang: Badan Penerbit UNDIP.

Lubis, I. P. S., (2019). Analisis Hubungan Persepsi Risiko Dengan Perilaku Berkendara Terhadap Risiko Kecelakaan Pada Pengendara Sepeda Motor Di Departemen Teknik Industri FT USU, Medan: Universitas Sumatera Utara.

Salim, A., (2000). Manajemen Transportasi Cetakan Pertama. Kedua ed. Jakarta: Ghalia Indonesia.

Sumantri, A. S., (2018). Studi Keterampiran Berkendara Terhadap Perilaku Aman Berkendara Pada Taruna STIMART "AMNI" Semarang. Jurnal Sains dan Teknologi Maritim, 17(2). 